\title{
Does postponing minimum retirement age improve healthy behaviours before retirement? Evidence from middle-aged Italian workers
}

Citation for published version (APA):

Bertoni, M., Brunello, G., \& Mazzarella, G. (2016). Does postponing minimum retirement age improve healthy behaviours before retirement? Evidence from middle-aged Italian workers. ROA. ROA Research Memoranda No. 007 https://doi.org/10.26481/umaror.2016007

Document status and date:

Published: 01/01/2016

DOI:

10.26481/umaror.2016007

Document Version:

Publisher's PDF, also known as Version of record

Please check the document version of this publication:

- A submitted manuscript is the version of the article upon submission and before peer-review. There can be important differences between the submitted version and the official published version of record.

People interested in the research are advised to contact the author for the final version of the publication, or visit the DOI to the publisher's website.

- The final author version and the galley proof are versions of the publication after peer review.

- The final published version features the final layout of the paper including the volume, issue and page numbers.

Link to publication

\footnotetext{
General rights rights.

- You may freely distribute the URL identifying the publication in the public portal. please follow below link for the End User Agreement:

www.umlib.nl/taverne-license

Take down policy

If you believe that this document breaches copyright please contact us at:

repository@maastrichtuniversity.nl

providing details and we will investigate your claim.
}

Copyright and moral rights for the publications made accessible in the public portal are retained by the authors and/or other copyright owners and it is a condition of accessing publications that users recognise and abide by the legal requirements associated with these

- Users may download and print one copy of any publication from the public portal for the purpose of private study or research.

- You may not further distribute the material or use it for any profit-making activity or commercial gain

If the publication is distributed under the terms of Article $25 \mathrm{fa}$ of the Dutch Copyright Act, indicated by the "Taverne" license above, 
Does postponing minimum retirement age improve healthy behaviours before retirement? Evidence from middle-aged Italian workers

Marco Bertoni

Giorgio Brunello

Gianluca Mazzarella

\section{ROA Research Memorandum}

ROA-RM-2016/7

Researchcentrum voor Onderwijs en Arbeidsmarkt | ROA

Research Centre for Education and the Labour Market | ROA 


\title{
Does postponing minimum retirement age improve healthy behaviours before retirement? Evidence from middle-aged Italian workers
}

\author{
Marco Bertoni \\ Giorgio Brunello \\ Gianluca Mazzarella
}

ROA-RM-2016/7*

March 2016

Research Centre for Education and the Labour Market

Maastricht University

P.O. Box 616, 6200 MD Maastricht, The Netherlands

$\mathrm{T}+31433883647 \mathrm{~F}+31433884914$

secretary-roa-sbe@maastrichtuniversity.nl

www.roa.nl

\footnotetext{
* The ROA Research Memorandum Series was created in order to make research results available for discussion, before those results are submitted for publication in journals.
} 


\section{Abstract \\ Does postponing minimum retirement age improve healthy behaviours before retirement? \\ Evidence from middle-aged Italian workers**}

By increasing the residual working horizon of employed individuals, pension reforms that raise minimum retirement age are likely to affect the returns to investments in healthpromoting behaviours before retirement, with consequences for individual health. Using the exogenous variation in minimum retirement age induced by a sequence of Italian pension reforms during the 1990s and 2000s, we show that Italian males aged 40 to 49 reacted to the longer time to retirement by raising regular exercise and by reducing smoking and regular alcohol consumption. Dietary habits were also affected, with positive consequences on obesity and self-reported satisfaction with health.

JEL classification: $\mathrm{H} 55$, I12, J26

Keywords: retirement, working horizon, healthy behaviours, pension reforms

\author{
Marco Bertoni \\ Department of Economics and \\ Management "Marco Fanno" \\ University of Padua \\ Via del Santo 33 \\ 35123 Padova \\ Italy \\ marco.bertoni@unipd.it
}

Gianluca Mazzarella

Department of Economics and

Management "Marco Fanno"

University of Padua

Via del Santo 33

35123 Padova

Italy

gianluca.mazzarella@unipd.it

\author{
Giorgio Brunello \\ Department of Economics and \\ Management "Marco Fanno" \\ University of Padua \\ Via del Santo 33 \\ 35123 Padova \\ Italy \\ giorgio.brunello@unipd.it \\ and IZA
}

\footnotetext{
** We thank Martina Celidoni, Michele De Nadai, Jan Marcus, Giacomo Pasini, Lorenzo Rocco, Adriana Topo, Elisabetta Trevisan, Guglielmo Weber, Felix Weinhardt, Francesca Zantomio and the audiences at seminars in Berlin, Padova and Venice for comments and suggestions. Marco Bertoni and Giorgio Brunello gratefully acknowledge financial support from the POPA_EHR project at the University of Padova. The usual disclaimer applies.
} 


\section{Introduction}

There is substantial research in health economics exploring the causal effects of retirement on individual health and health behaviours. This literature consistently reports that the transition into retirement has positive short-term effects both on self-reported health and on indices of physical health. Recent evidence includes Insler, 2014, for the U.S., Coe and Zamarro, 2011, and Eibich, 2015, for Europe and Zhao et al., 2013, for Japan. Some studies emphasize the positive changes in health-promoting behaviours - such as additional physical exercise and reductions in drinking and smoking - when explaining the positive effects of retirement on overall health (Celidoni and Rebba, 2015, and Kaempfen and Maurer, 2016). ${ }^{1}$ These positive effects, however, may be short-lived and disappear with time (the so-called 'honeymoon effect' of retirement). ${ }^{2}$

The causal impact of retirement on health is typically identified using the exogenous variation provided by changes in the eligibility conditions for early or full retirement, that affect retirement patterns without having a direct impact on health (see Coe and Zamarro, 2011). These changes, however, affect not only the individuals who are close to eligibility, but also younger individuals, and in particular those who - in the absence of constraints would choose an optimal retirement age that falls below the minimum required by retirement rules. Therefore, optimal health behaviours may change even before retirement.

Compared to the growing evidence on the impact of retirement on health, less is known on the effects of a longer working horizon on individual behaviours before retirement, and what

${ }^{1}$ Conversely, Godard, 2016, finds that the retirement transition has a positive effect on the incidence of obesity among European workers. This effect is particularly pronounced among those who were employed in blue-collar and physically demanding jobs. The studies on the effects of retirement on cognition generally find negative effects (see Rohwedder and Willis, 2010, Adams et al., 2012, Mazzonna and Peracchi, 2012, and Celidoni et al., 2013). The evidence is less clear-cut for mental health (see Charles, 2004, Börsch-Supan and Jürges, 2009, Johnston and Lee, 2009, Clark and Fawaz, 2009, Bonsang and Klein, 2012, Bertoni and Brunello, 2014, and Fonseca et al., 2015).

${ }^{2}$ For instance, Mazzonna and Peracchi, 2014, and Bertoni et al., 2015, estimate that - given age - a longer time spent in retirement has a negative effect on an index of overall physical health and on muscle strength, a robust predictor of disability, cardiovascular diseases and mortality. 
is known does not include health-promoting behaviours. Hairault et al., 2010, for instance, shows that French workers exposed to an exogenous increase in their expected retirement age increase job search effort. They explain this finding by showing that the economic returns to jobs depend on their expected duration, which increases with retirement age. Following a similar argument, Montizaan et al., 2010, and Brunello and Comi, 2015, use Dutch and Italian data and show that policies that increase the residual working horizon have positive consequences on training participation by active older workers. ${ }^{3}$ In a study especially close to ours, De Grip et al., 2012, find that a Dutch reform reducing pension rights and postponing the minimum retirement age of public sector workers has reduced their mental health.

In this paper, we use data on several cohorts of middle aged Italian working men during the period 1997 to 2011 to study the impact of changes in minimum retirement age - induced by reforms affecting eligibility conditions - on health-promoting behaviours before retirement. By considering only male workers aged 40 to 49 , we focus on individuals who are generally not eligible for retirement and at the same time are not too far from it. Changes in healthpromoting behaviours affect health. Health before retirement is likely to be higher among middle aged men if better health increases the net utility gains associated to a longer working horizon. For instance, if earnings and employment in the additional period before retirement depend on health, affected individuals have an incentive to keep fit so as to reap these benefits.

Italy provides an interesting setup for the issue at hand, because of the sequence of pension reforms that occurred during the period under study (see e.g. Angelini et al., 2009). Even before these reforms, eligibility for early retirement required in most cases that social security contributions be paid for at least 35 years. The sequence of reforms progressively tightened eligibility requirements in terms of both age and accrued years of contributions, thereby

3 Montizaan and Vendrik, 2014, find that the same policies negatively affected job satisfaction of treated Dutch workers. A longer working horizon may also have intergenerational consequences on the children of potential retirees. Manacorda and Moretti, 2006, find negative effects of a longer parental working horizon (and thus higher parental income) on the nest-leaving decisions of Italian youngsters. Battistin, et al., 2014, find that policies raising the retirement age have negatively affected the supply of informal childcare provided by Italian grandparents, thereby reducing the number of grandchildren. 
generating exogenous variation in the expected minimum retirement age for comparable workers observed in different years - when different retirement laws were in place.

We study the effects of changes in minimum retirement age on health-promoting behaviours, including regular exercise, refraining from smoking and drinking alcohol regularly, and dietary habits such as refraining from eating red meat or imbibing soft drinks at least once a day, and eating fruit or vegetables at least once a day. We also consider the effects on the body mass index. ${ }^{4}$

Our empirical approach relies on instrumental variables. In Italy, the minimum time to retirement combines age requirements - that are clearly exogenous - and requirements on the years of paid social security contributions, that depend on individual careers and are likely to be endogenous, because negative health shocks affect both health behaviours and working careers. We instrument minimum actual years to retirement, computed using information on the actual years of paid contributions, with minimum potential years to retirement - obtained by replacing the number of years of paid social security contributions with potential experience - measured as age minus school leaving age, a pre-determined variable in our setup. Conditional on age-by-school leaving age dummies, sector dummies and non-linear trends in birth cohort, the only remaining source of variation in the instrument is generated by the different retirement rules in place in different years - which are exogenous to individual choices.

We find that a one-year increase in minimum actual years to retirement increases the likelihood of exercising regularly by 3.28 percentage points (equivalent to 15.74 percent of the mean value of the outcome in the full sample) and the likelihood of refraining from smoking and drinking regularly by 3.22 and 2.50 percentage points (equivalent respectively to 4.88 and 5.40 percent of the mean value of the outcome in the full sample). There is also evidence that a longer time to retirement reduces the consumption of red meat and soft drinks, and the prevalence of obesity, although these estimated effects are imprecise. Overall, self-reported high satisfaction with own health also increases.

We hasten to stress that the range of health behaviours observed in our data does not exhaust all the important behaviours that may affect health. For instance, we do not have information on the use of illicit drugs or unsafe sex. Yet our evidence is highly suggestive that postponing retirement may improve health before retirement.

\footnotetext{
${ }^{4}$ Cawley and Ruhm, 2011, treat obesity as an health behaviour.
} 
During the sample period 1997 - 2011, mean years to retirement in our data increased by about three years. Back-of-the-envelope calculations suggest that the longer minimum working horizon has had important effects on measured health-promoting behaviours, raising the frequency of regular exercise by more than 9.8 percentage points - equivalent to more than 40 percent of the mean value of the outcome in the full sample, a large amount - and reducing the incidence of smoking and regular drinking by 9.6 and 7.5 percentage points, equivalent respectively to about 15 and 16 percent of the mean value of the outcomes in the full sample.

Since these effects are sizeable, especially for physical activity, a natural concern is that the observed trend in minimum retirement age is capturing the negative trend in several risky health behaviours, described for instance by Cawley and Ruhm, 2011, for the United States, and by the OECD, 2015. To dispel this concern, we control for the long-term changes in behaviours that are not attributable to pension reforms by including in our regressions a time-varying index of each behaviour for individuals not affected by these reforms (males aged 65 to 75 ) or only marginally affected (females aged 40 to 49 who are not in the labour force or males aged 25 to 30). However, irrespectively of the chosen control group, our qualitative results are unchanged.

Understanding the effects of a longer working horizon on behaviours before retirement is important. Several OECD countries have recently introduced pension reforms that raise minimum retirement age in order to deal with the increased burden of population ageing on public finances. By delaying retirement and by increasing the residual working horizon of employed individuals, these reforms may generate unexpected costs and benefits. In this paper, we highlight that one benefit could be better health before retirement, as constrained individuals react to the longer horizon by investing in healthy behaviours and reducing unhealthy ones. Ceteris paribus, in countries with universalistic public health care, better health before retirement may generate important savings, and these savings should be accounted for when evaluating the impact of pension reforms.

The paper is organized as follows. In Section 1, we introduce the institutional background and the sequence of pension reforms affecting minimum retirement age in Italy. Section 2 presents the data. We discuss the empirical setup in Section 3 and results in Section 4. Conclusions follow. 


\section{Institutional Background: Recent Italian Pension Reforms}

To cope with the fiscal consequences of population ageing, starting from the early 1990s many European countries - including Italy - have undertaken structural changes in their social security systems, including significant increases in minimum retirement age. In this paper, we focus on the sequence of Italian social security reforms that took place between 1997 and 2011 - the period covered by our data - and repeatedly changed retirement eligibility rules. ${ }^{5}$

Before 1992, the minimum age for old-age pension for men was 60 for employees in the private sector and for self-employed workers, and 65 for public sector employees conditional on having paid social security contributions for at least 15 years. Early retirement with a seniority pension was instead possible at any age for workers who had paid social security contributions for at least 35 years. $^{6}$ The first social security reform (the so-called "Amato" reform - from the name of the Prime Minister at the time of its implementation) took place in 1992 and introduced a progressive increase in the requirements for eligibility to old age pensions, that were expected to reach at least 20 years of paid contributions and age 65 by 2001, as shown in Table A1 in the Appendix.

In 1995, a second major reform (the "Dini" reform) tightened the eligibility requirements for seniority pensions, that were to raise gradually from 1996 to 2008 until either 40 years of paid contributions independently of age, or 57 years of age and 35 years of paid contributions. ${ }^{7}$ The reform also prescribed a faster increase of eligibility requirements for the self-employed, as documented in Table A2 in the Appendix, where we summarize all changes in seniority pension eligibility rules introduced by the reforms of interest. After only

${ }^{5}$ We exclude the Fornero reform, that substantially changed eligibility rules in 2012 . See Angelini et al., 2009, and Bottazzi et al., 2011, among others for further details on the pension reforms occurring during our sample period.

${ }^{6}$ Since our empirical analysis is restricted to men, we do not discuss here the changes in pension eligibility rules that apply to females.

${ }^{7}$ By introducing eligibility requirements for seniority pensions, this reform abolished the socalled "baby-pensions", that since 1973 allowed public employees with at least 20 years of paid contributions to retire independently of age. This requirement was set as low as 14 years, 6 months and 1 day for married women with children who were employed in the public sector. 
three years, in 1998, pension eligibility rules changed again with the "Prodi" reform, that accelerated the transition period and increased the minimum retirement age to 58 for the selfemployed.

The fourth reform took place in 2005, when Welfare Minister Roberto Maroni changed again the eligibility requirements for seniority pensions, introducing a sharp 3-year increase in minimum eligibility age (the so-called "scalone") from 57 to 60 years for public and private employees, and from 58 to 61 for the self-employed, starting from year 2008. However, in 2007, the new left-wing government led by Romano Prodi (or "Prodi bis") postponed the proposed 3-year increase to 2011, introducing instead a gradual adjustment in the requirements, starting again from 2008, as documented in Table A2. For this reason, no worker has actually retired under the requirements prescribed by the "Maroni" reform. Yet, this reform is still relevant for our purposes, as it changed the expected minimum retirement age for workers during the years from 2005 to 2008. In addition, under the "Prodi bis" regime, eligibility to seniority pensions was made conditional to achieving a further threshold, defined in terms of the sum of age and years of contributions - that also varies by year of retirement and sector (see Table A2).

This sequence of reforms has generated exogenous variation in the minimum retirement age of workers with the same age, who have paid social security contributions for the same number of years and belong to the same sector, but are observed in different years (i.e. were born in different cohorts), when different retirement laws were in place. To isolate this variation from endogenous changes in the length of working careers, we define potential years to retirement $P Y R$ at time $t$ as the minimum number of years to retirement prescribed by the law in place at the time, when the years of paid social security contributions are set equal to the years of potential labour market experience, or the difference between age and school leaving age. ${ }^{8}$ This measure differs from actual years to retirement $Y R$, that are based instead on actual rather than potential labour market experience.

We illustrate how PYR varies over time with the example shown in Table 1, where we consider hypothetical private sector employees aged 40, 45 and 49 in 1991, 1997, 2001, 2007 and 2011, who started their continuous careers at age 19, after completing secondary school.

${ }^{8}$ By so doing, we are assuming that individual labour market careers are continuous. We compute school leaving age as the canonical number of years required to complete the highest attained school degree plus six - the school starting age. 
It turns out that PYR increased from 14 in 1991 to 19 in 2011 for those aged 40, from 9 to 14 years for those aged 45 and from 5 to 10 for those aged 49. Especially for older workers, the bulk of this increase occurred between 1997 and 2011.

Pension reforms in Italy have also modified pension benefits. The major change occurred in 1995, before the start of our sample period, with the transition from a system based on defined benefits to a system using defined contributions. Another important change occurred instead during our sample period, when in 2007 the second Prodi government ("Prodi bis") reduced the coefficients used to transform accumulated contributions into pension benefits for workers retiring from 2010 onwards. Since this change could have altered health behaviours independently of the changes in minimum retirement age, we account for it in our empirical analysis.

\section{The Data}

Our data consist of two samples, a main and an auxiliary sample. The main sample is from the survey "Aspetti della Vita Quotidiana" (Aspects of Daily Life, hereafter AVQ), carried out on a yearly basis by the Italian Bureau of Statistics (ISTAT), and the auxiliary sample is from the Survey on the Income and Wealth of Italian Households (SHIW from now on), conducted on a bi-annual basis by the Bank of Italy.

AVQ is a cross-sectional annual survey implemented on a sample of about 50,000 individuals. It covers several aspects of daily life, including behaviours such as exercising, smoking, drinking and dietary habits. We use the waves from 1997 to 2011 (for a total of 14 different years, as in 2004 the survey did not took place), and focus on middle aged (age 40 to 49) males, who are generally too young to be retired but not too far from retirement. We exclude females because their labour market careers - a crucial aspect of our empirical exercise - are often more discontinuous than those of men because of childbearing responsibilities. After eliminating from the sample the very few who are retired, disabled or have never worked in their life, as well as those with missing values in the variables used in the analysis we end up with a final sample of 38,966 individuals.

We construct the following indicators of healthy lifestyles: a dummy equal to 1 if the individual exercises on a regular basis, and 0 otherwise; a dummy equal to 1 if he does not smoke, and 0 otherwise; a dummy equal to 1 if he does not drink alcohol regularly and 0 
otherwise; ${ }^{9}$ a dummy equal to 1 if he refrains from eating red meat at least once a day and 0 otherwise; a dummy equal to 1 if he eats vegetables or fruit at least once a day, and 0 otherwise; a dummy equal to 1 if he refrains from imbibing soft drinks at least once a day, and 0 otherwise; and a dummy equal to 1 if his BMI is below 30 (not obese), and 0 otherwise. We also define as indicator of health satisfaction a dummy equal to 1 if the individual is very satisfied with his own health, and 0 otherwise.

We plot in Figure 1 for our sample period the average values of these indicators as well as PYR. On the one hand, the percentages exercising regularly, not smoking and not drinking regularly have increased over time; on the other hand, the percentage not eating red meat at least once a day has been rather stable, and the percentages eating fruits and veggies and refraining from drinking soft-drinks at least once a day - available only since 1998 - have declined. Figure 2 shows that the percentage not obese - available only from 2001 - and the percentage reporting very good health are more or less constant over time.

The AVQ survey includes also variables that we use as additional covariates in our regressions: age, educational attainment, sector of employment (private, public or selfemployment), type of job (whether physically demanding or not), type of accommodation, marital status and presence of children. While the survey has data on individual current labour market status, there is no information on previous labour market history. Because of this, the total years of paid social security contributions are not available, and we can only construct their potential value $P Y R$.

We supplement this information with that from our auxiliary sample, that has data on (self reported) years of paid social security contributions at the time of the interview, but is silent on health-promoting behaviours. This sample consists of 8,549 males aged 40 to 49 from 1998 to 2010 (7 different surveys), for whom we can compute both PYR and $Y R .^{10}$

Table 2 presents the summary statistics of the variables introduced in this section. In our main sample, 21 percent of the individuals exercise regularly, 66 percent do not smoke, 46 percent do not drink alcohol regularly, 83 percent do not eat red meat at least once a day, 85 percent

\footnotetext{
${ }^{9}$ We define regular drinking if the individual drinks at least 1 or 2 glasses of either wine or beer per day, or if he drinks alcohol outside meals on a daily basis. Our data do not have information on binge drinking.

10 The main and the auxiliary sample are broadly comparable in terms of observable characteristics.
} 
eat fruits or vegetables at least once a day, 86 percent do not drink soft drinks at least once a day and 89 percent is not obese. In addition, 20 percent are very satisfied with their health. While the actual minimum number of years to retirement $Y R$ is 15.24 , the potential number PYR is about three years shorter at 12.23. The percentage of individuals with at least a high school diploma is 43 percent; 29 percent are self-employed and 18 percent are public sector employees; 67 percent live in a standard apartment, 84 percent are married and 19 percent have no children. Finally, 31 percent work in a physically demanding job.

\section{The Empirical Approach}

Galama et al., 2013, have recently developed a structural model of consumption, leisure, health, health behaviours, wealth accumulation and retirement decisions using the human capital framework of health developed by Grossman, 2000. We present in the Appendix a simplified version of Galama et al.'s model with the purpose of illustrating how changes in minimum retirement age $\mathrm{R}_{\min }$ affect healthy behaviours.

In this model, the health stock is in the utility function both during working life and during retirement and also affects earnings during working life. Individuals cannot modify their health stock directly but can invest in costly healthy behaviours, which affect current and future health. The optimal health investment before retirement equalizes the marginal current and future benefits of better health to the marginal costs of attaining it. Optimal retirement age $R$ is also subject to choice, and it is jointly determined with consumption and investment in healthy behaviours.

Exogenous changes in minimum retirement age $\mathrm{R}_{\text {min }}$ affect only the individuals with an optimal retirement age equal to or lower than $\mathrm{R}_{\min }$. For these individuals, an increase in $\mathrm{R}_{\min }$ promotes investment in healthy behaviours if the marginal benefits of better health during the additional period of active working life - in terms of higher utility and earnings are higher than the marginal costs - in terms of the investment costs and of the foregone benefits due to the shorter retirement period.

Let the optimal time to retirement chosen by an individual aged $A$ in the absence of any constraint be $\mathrm{YR}^{*}=\mathrm{R}-\mathrm{A}$. Let instead $Y R$ be the actual minimum time to retirement, that depends on the set of exogenous retirement rules $\left\{\mathrm{R}_{\min }, \mathrm{CS}{ }_{\min }\right\}$, where $\mathrm{CS}_{\min }$ is the minimum number of years of paid social security contributions required to access early 
retirement, on individual age, and on accumulated social security contributions at age $A$, defined as $C S$.

By modifying $\mathrm{R}_{\min }$ and $\mathrm{CS}_{\min }$, policy makers can alter minimum time to retirement, which in turn affects the behaviour of individuals for whom $\mathrm{YR}^{*} \leq \mathrm{YR}$ holds. We model the empirical relationship between actual minimum years to retirement and healthy behaviours as follows

$$
\mathrm{B}_{\mathrm{it}}=\alpha+\beta \mathrm{YR}_{\mathrm{it}}+\gamma \mathrm{X}_{\mathrm{it}}+\varepsilon_{\mathrm{it}}
$$

where the indices $i$ and $t$ are for the individual and time, $B$ is for healthy behaviours, $X$ is a vector of controls, that includes age by school leaving age dummies, dummies for sector of employment and a cubic trend in cohort of birth, and $\varepsilon$ is the error term. Since our sample consists of male workers aged 40 to 49 and in Italy transitions from a sector to another are infrequent in this age range, ${ }^{11}$ we treat both school leaving age and sector of employment as pre-determined variables.

The parameter $\beta$ measures the marginal effect of a one-year increase in the actual minimum time to retirement on healthy behaviours. Denote with $s$ the share of individuals with $\mathrm{YR}^{*} \leq \mathrm{YR}$ and assume that $\beta_{\mathrm{u}}$ and $\beta_{\mathrm{c}}$ are the marginal effects of $Y R$ on $B$ for the sub-groups with $\mathrm{YR}^{*}>\mathrm{YR}$ and $\mathrm{YR}^{*} \leq \mathrm{YR}$, respectively. Then $\beta=\frac{\partial B}{\partial Y R}=\beta_{c} s\left[1+\frac{\partial s}{\partial Y R} \frac{Y R}{s}\right]$, because $\beta_{\mathrm{u}}=0$. Therefore, the estimated marginal effect of $Y R$ in (1) compounds the effect on the sub-group with $\mathrm{YR}^{*} \leq \mathrm{YR}$ and the effect on the share of individuals who are constrained by the minimum retirement age.

As discussed in Section 2, the sequence of pension reforms introduced by Italian governments during the 1990s and 2000s repeatedly modified both the minimum retirement

${ }^{11}$ Using quarterly data from the Italian Labour Force Survey, we estimate the following yearto-year average transition rates across sectors for workers aged 40 to 49 during the years 2004 to 2011: 1.44 percent from self-employed to private sector employee; 0.23 percent from self-employed to public sector employee; 0.09 percent from private to public sector employee; 0.25 percent from private sector employee to self-employed; 0.08 percent from public to private sector employee and 0.03 percent from public sector employee to selfemployed. 
age $\mathrm{R}_{\min }$ and the minimum number of years of paid social security contributions $\left(\mathrm{CS}_{\min }\right)$ required to access to retirement with a seniority pension. These changes - that have been specific to the self-employed and to public and private sector employees - have generated variability over time in the minimum number of years to retirement among workers of the same age, who paid social security contributions for the same number of years and belong to the same sector (i.e. private, public, self-employed).

Since eligibility requires a minimum number of years of paid social security contributions, $Y R$ is shorter for workers with no employment gaps in their careers, even conditional on age, sector and school leaving age. One reason for observing discontinuous careers is the experience of negative health shocks - either currently or in the past - which in turn may depend on the adoption of unhealthy behaviours. These shocks generate reverse causality, as people who experience bad health - or adopt unhealthy behaviours - also end up having a longer working horizon. In this case, conditioning on vector $X$ does not suffice in preventing OLS estimates of $\beta$ in Eq. (1) from being inconsistent.

We address reverse causality by instrumenting $Y R$ with $P Y R$, the potential years to retirement, or the minimum residual working horizon under the assumption of continuous careers. Contrarily to $Y R$, the selected instrument does not depend on individual careers and varies with age, retirement eligibility conditions and education, that are either exogenous or predetermined for the relevant age group (40 to 49). Conditional on the variables in vector $X$, the residual variation in $P Y R$ is due exclusively to the changes in retirement rules that took place over the years - which we treat as exogenous to individual behaviour.

In the reduced form equation,

$B_{i t}=\alpha_{R}+\beta_{R} P_{\text {PR }}+\gamma_{R} X_{i t}+\varepsilon_{R i t}$

the identification of parameter $\beta_{\mathrm{R}}$ as the intention to treat effect of $P Y R$ on $B$ requires that, conditional on vector $X, P Y R$ is as good as randomly assigned. In support to this assumption, we show that - as one would expect if $P Y R$ can be treated as random given $X$ - the estimates of $\beta_{\mathrm{R}}$ in (2) are broadly unaffected by the inclusion of an additional set of pre-determined covariates that are likely to correlate with $B$ - including dummies for region of residence, type of accommodation (a proxy for wealth), marital status, the presence of kids and working in physically demanding jobs. The estimated value of $\beta_{\mathrm{R}}$ is also largely unaffected when we add time-varying macroeconomic factors (GDP per capita and the relative prices of each 
outcome of interest), that are likely to influence the adoption of healthy behaviours and to correlate with changes in eligibility requirements.

In a similar fashion, if healthy behaviours exhibit a long-term positive trend and this trend is not included in (2), a positive correlation between $B$ and $P Y R$ may simply reflect the omitted trend rather than the effect of pension reforms. To avoid this, we estimate a specification of (2) that includes as an additional control the variable $\overline{\mathrm{B}}_{\mathrm{gt}}$, defined as the average regional value of $B$ for three alterative groups (g): a) males aged 65 to 75, who are not affected by pension reforms; b) females out of the labour force and aged 40 to 49 , who are also unlikely to be affected; c) young males aged 25 to 30, who are far enough from retirement to disregard changes in PYR in their current behaviours. As reported below, we find that - independently of the selected control group - the estimates of $\beta_{\mathrm{R}}$ are only marginally affected.

The identification of parameter $\beta$ in Eq. (1) as the (Local) Average Treatment Effect of $Y R$ on $B$ requires two additional conditions: first, we need a significant first-stage relationship between $Y R$ and the selected instrument $P Y R$. Visual evidence that such relationship exists is reported in Figure 3, where we plot the distribution of $Y R$ and $P Y R$ in our auxiliary sample, as well as the linear regression fit, showing a strongly positive association between the two. Formal evidence is discussed in the next section. Second, we require that $P Y R$ influences $B$ only via its effect on $Y R$, a tenable exclusion restriction in this context. ${ }^{12}$

As described in the previous section, our key data source - the ISTAT AVQ survey - has detailed information on the adoption of healthy behaviours, but no information on the years of paid social security contributions. Since we cannot compute $Y R$ using these data, we can only estimate the reduced form equation (2). We estimate parameter $\beta$ in Eq. (1) using our auxiliary SHIW sample and Two-Sample Instrumental Variables (TSIV) (see Angrist and Krueger, 1992 and Inoue and Solon, 2010). ${ }^{13}$ Letting $\pi$ be the effect of PYR on $Y R$ in the first

${ }^{12} \mathrm{We}$ also require a monotonicity condition (see Imbens and Angrist, 1994), stating that exposure to longer $Y R$ cannot lead to shorter $P Y R$.

${ }^{13}$ We estimate the first stage using data for 1998, 2000, 2002, 2004, 2006, 2008 and 2010. Even if we observe in this dataset the accrued years of social security contributions, we still need to assume continuous careers from the time of observation until retirement (see Battistin et al., 2009). 
stage regression, our IV estimate of parameter $\beta$ is obtained as the ratio $\beta=\frac{\beta_{\mathrm{R}}}{\pi} \cdot{ }^{14}$ In all regressions, we cluster standard errors by cohort, sector and school leaving age.

We estimate equations (1) and (2) for each behaviour separately. However, since the error terms associated to the different behaviours can be correlated, we also jointly estimate the system of reduced form equations using seemingly unrelated regressions, but find no significant change in the standard errors. We also test whether the coefficients associated to $P Y R$ in the reduced form equations are jointly equal to zero, and strongly reject this hypothesis (p-value $<0.01)$.

\section{Empirical Results}

If pension reforms that raise minimum retirement age affect at least part of the relevant population, and workers understand the effects of these changes, average expected retirement age should raise as $Y R$ increases. To document that this is the case, we use our auxiliary sample drawn from SHIW - where individuals are asked about their expected retirement age - and regress expected retirement age on minimum age and on the vector of controls $X$. We estimate that a one year increase in minimum retirement age raises expected age by about half a year $(0.54$, standard error 0.02$){ }^{15}$

We estimate equation (2) using a linear probability model and report in Table 3 the estimated effects of potential minimum time to retirement $P Y R$ on healthy behaviours. The table reports both the estimated coefficients (multiplied by 100) and the percentage effects computed with respect to the mean of the outcome variable. Panel 1 is for the most parsimonious specification, that only includes vector $X$; panel 2 includes additional individual controls; panel 3 further includes the real GDP per capita, the relevant relative price - measured as the price of the outcome relative to the average price - and $\overline{\mathrm{B}}_{\mathrm{gt}}$, the regional value of $B$ for males aged 65 to 75, who are not affected by changes in PYR; panels 4 and 5 are similar to panel 3

\footnotetext{
${ }^{14}$ Inference is carried out by bootstrapping. Notice that, since there is a single endogenous variable and the model is just identified, our estimation procedure is equivalent to a TwoSample Two-Stage Least Squares procedure, which involves computing the fitted values of $Y R$ in the ISTAT AVQ data using the first-stage coefficients estimated in SHIW.

${ }^{15}$ See Bottazzi et al., 2006, for additional evidence.
} 
except that we use the regional trends in the relevant outcome for males aged 25 to 30 and for females aged 40 to 49 who are out of the labour force.

Focusing on Panel 1, we find that increasing the residual (potential) working horizon PYR significantly improves several healthy behaviours. We estimate that a 1-year increase in PYR raises the probability of practicing sports regularly by 5.92 percent and reduces the probability of smoking and drinking alcohol on a regular basis by 1.83 and 2.03 percent respectively. These are statistically significant effects. In addition, increasing $P Y R$ by one year affects nutrition habits by reducing the likelihood of eating read meat and consuming soft drinks at least once a day by 0.69 and 0.78 percent respectively - although the former effect is statistically significant only at the 10 percent level. We also detect a small but imprecisely estimated positive effect of higher $P Y R$ on the consumption of fruits and vegetables. Consistently with these dietary improvements, there is also evidence that a higher value of $P Y R$ increase the probability of not being obese, albeit this effect is imprecisely estimated. ${ }^{16}$ Finally, we find that a longer time to retirement improves the probability of being very satisfied with own health.

Reassuringly for our identification strategy, introducing additional covariates to vector $X-$ see Panel 2 - does not change our results. Similarly, we do not detect stark changes in our findings even when we also add macroeconomic controls and regional trends in the outcome variable for males who are unaffected by the reforms, males very far from retirement age or females aged 40 to 49 who are out of the labour force - see Panels 3 to 5. Because of this, we will focus hereafter on the most parsimonious specification in Panel 1.

Our empirical findings are robust to several changes in specification. First, Table A3 in the Appendix shows that results are similar when we compute the marginal effects of $P Y R$ on behaviours using a Probit specification instead of a linear probability model. Second, we verify whether the linear relationship between behaviours $B$ and $P Y R$ - adopted in Eq. (2) - is overly restrictive by adding to our baseline specification a quadratic term in PYR. As reported in Table A4 in the Appendix, this term is never statistically significant at the conventional five percent level of confidence, which lends support to the baseline versus the quadratic

\footnotetext{
16 This effect is statistically significant at the ten percent level of confidence in less parsimonious specifications.
} 
specification. ${ }^{17}$ Next, we re-define our outcomes as ordinal variables, but out qualitative results are still unchanged. For instance, in the case of exercising we distinguish between no exercising, light physical activity, irregular and regular exercising, and find that an additional year to retirement has a negative and positive effect of similar size on the former two and latter two categories respectively.

Last but not least, we consider the potential confounding effects on our estimates of changes in pension replacement rates, that could have modified healthy behaviours independently of changes in PYR. The relevant change during our sample period is the method of computation of pension benefits, that was altered starting in 2007 for those who could retire from 2010 onwards. To control for this effect, we add a dummy equal to 1 for individuals observed in years 2007-2011 and eligible to retire since 2010, but find no change in our results. ${ }^{18}$

To investigate whether responses to changes in $Y R$ are heterogeneous, we estimate separate regressions by sector of activity (private employees, public employees, self-employed workers), level of education (below or above high school) and type of job (physically and not physically demanding job), and report results in Table 4 . We find that changes in minimum retirement age have virtually no effect on public sector workers and generally stronger effects among the better educated. On the one hand, the better educated may respond more to changes in minimum retirement age because they typically are more forward looking and more likely to incorporate future expected changes into their current behaviour. On the other hand, public employees in Italy have stronger job guarantees than private sector workers, and therefore may be less concerned with preserving their health in order to work longer. As expected, we also find that a longer time to retirement does not alter the likelihood of carrying out regular physical activity by those who are already engaged in a physically demanding job. ${ }^{19}$

We have presented so far the intention to treat effects of higher potential minimum time to retirement on healthy behaviours. We now turn to estimating the effects of the actual minimum time to retirement $Y R$ on these behaviours, using potential time $P Y R$ as the

\footnotetext{
$17 \overline{\text { A specification with dummies }}$ for each level of $P Y R$ also lends support to the linearity assumption.

${ }^{18}$ The results are available from the authors upon request.

${ }^{19}$ Since we find that regular working hours are unaffected by changes in PYR, we conclude that additional regular exercise occurs mainly during leisure time.
} 
instrument for actual time and Two-Sample Instrumental Variables. First, we regress actual time on potential time and the vector of control $X$ in our auxiliary SHIW sample, and report the result at the bottom of Table 5. According to our estimates, a 1-year increase in PYR increases $Y R$ conditional on $X$ by 0.38 years. Since the value of the first-stage F statistic for instrument weakness is 28.06 , well above the threshold of 10 , our instrument is not weak. Second, we compute for each behaviour the Two-Sample IV estimate of $\beta$ as $\frac{\beta_{R}}{\pi}$, and show our results in the first row of the table (multiplied by 100). We estimate that the $I V$ effects of $Y R$ on $B$ are about 2.5 times larger than the ITT estimates shown in Table 3 . When evaluated at mean values, a one-year increase in the actual minimum time to retirement increases the likelihood of exercising regularly by 15.74 percent and reduces smoking and drinking by 4.88 and 5.4 percent. We also confirm that higher time to retirement induces a reduction in the consumption of red meat and soft drinks and in obesity, although these estimates are often imprecise. Finally, health satisfaction increase by 9.23 percent (statistically significant at the 10 percent level).

These are sizeable effects, especially for physical activity. Back-of-the-envelope calculations show that, during the sample period 1997 - 2011, mean years to retirement in the SHIW sample increased from 17 to 20 for those aged 40 and from 8 to 11 for those aged 49 . Our estimates based on the linear specification and the Two-Sample IV method indicate that these changes have had important effects on healthy behaviours, raising the average probability of regular exercising from 0.21 to $0.30(+45 \%)$, of not smoking from 0.66 to $0.77(+16 \%)$ and of not drinking regularly from 0.46 to $0.52(+13 \%)$.

\section{Conclusions}

We have investigated the effects of postponing minimum retirement age on healthy behaviours before retirement using data on several cohorts of middle aged Italian working men during the period 1997 to 2011, when repeated pension reforms took place in an effort to contain public expenditure. Because these reforms generated exogenous variation in minimum retirement age, Italy is an interesting laboratory to study the issue at hand.

While much research has been devoted to establishing whether and how retirement affects the health of retired individuals, less has been done to understand whether policy measures that alter the length of the residual working horizon can affect health and healthy behaviours even 
before retirement. We have estimated the causal effect of changes in the potential as well as actual minimum number of years to retirement on the health lifestyles of Italian workers aged 40 to 49 , who can be 8 to 20 years away from minimum retirement age, and found that when evaluated at the mean value of each outcome - a one-year increase in minimum actual years to retirement raises the likelihood of exercising regularly by 15.74 percent and reduces smoking and regular drinking by 4.88 and 5.4 percent. Furthermore, a longer time to retirement increases the probability that red meat and soft drinks are consumed less, and that fruit and vegetables are consumed more frequently. Because of the improvement in dietary habits, there is also some evidence that obesity declines. Consistently with these findings, we also estimate a positive effect on self-reported high satisfaction with health.

Pension reforms that raise minimum retirement age have been introduced in several OECD countries to deal with the increased burden of population ageing on public finances. By delaying retirement and by increasing the residual working horizon of employed individuals, these reforms may reap unexpected dividends. We have highlight that one such dividend could be better health before retirement, as constrained individuals react to the longer horizon by investing in healthy behaviours and reducing unhealthy ones. Better health before retirement may generate important savings to private and public expenditure, and these savings should be accounted for when evaluating the overall impact of pension reforms. 


\section{Figures and Tables}

Figure 1. Potential years to retirement (PYR) and average healthy behaviours. Years 1997-2011
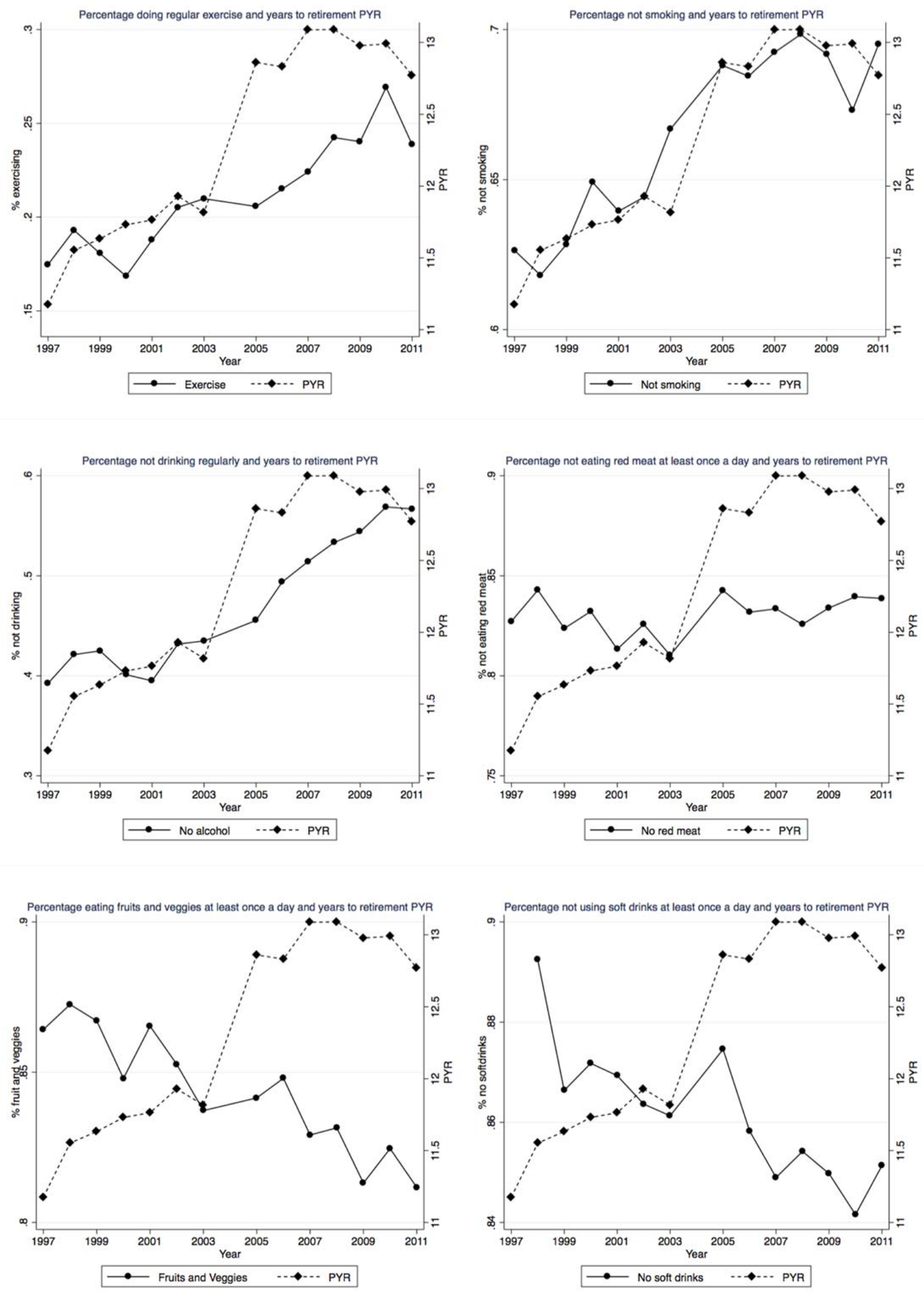
Figure 2. Potential years to retirement (PYR), obesity and self - reported good health. Years 19972011
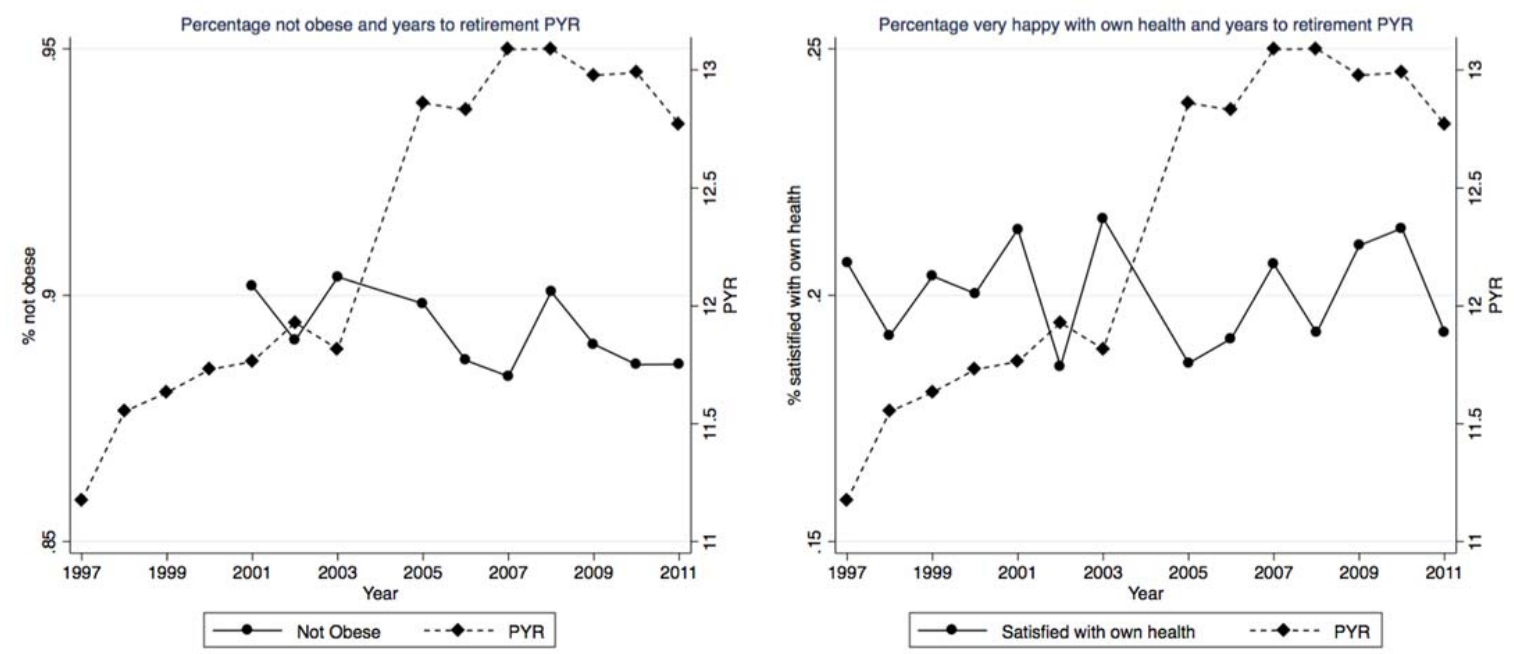
Figure 3. Years to retirement: $Y R$ and $P Y R$ - Bank of Italy SHIW data 1998-2010.

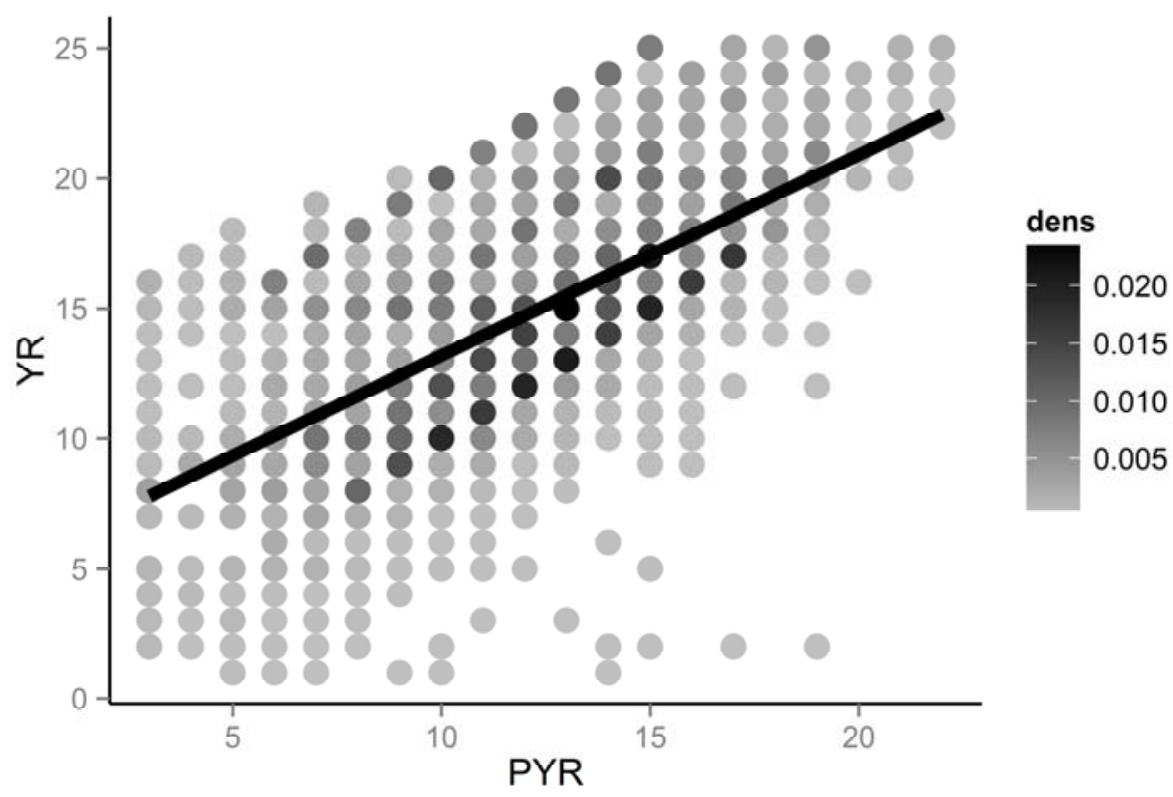

Notes: the figure reports a scatterplot and a linear fit of $Y R$ on $P Y R$ in Bank of Italy SHIW data from 1998 until 2010. Micro-data are collapsed by YR and PYR. Darker dots indicate cells with higher density. The linear fit is obtained from micro-data. 
Table 1. Simulated potential years to retirement (PYR) for workers aged 40, 45 or 49 , starting to work at 19, observed in 1991, 1997, 2001, 2007, and 2011.

\begin{tabular}{ccccc}
\hline Age & Year & Reform & Contributions paid & PYR \\
\hline & & & & \\
40 & 1991 & - & 21 & 14 \\
40 & 1997 & Dini & 21 & 17 \\
40 & 2001 & Prodi & 21 & 17 \\
40 & 2007 & Maroni & 21 & 19 \\
40 & 2011 & Prodi Bis & 21 & 19 \\
& & & & \\
45 & 1991 & - & 26 & 9 \\
45 & 1997 & Dini & 26 & 12 \\
45 & 2001 & Prodi & 26 & 14 \\
45 & 2007 & Maroni & 26 & 14 \\
45 & 2011 & Prodi Bis & 26 & 14 \\
& & & & \\
49 & 1991 & - & 30 & 5 \\
49 & 1997 & Dini & 30 & 6 \\
49 & 2001 & Prodi & 30 & 8 \\
49 & 2007 & Maroni & 30 & 10 \\
49 & 2011 & Prodi Bis & 30 & 10 \\
\hline
\end{tabular}

Notes: see Tables A1 and A2 for pension eligibility requirements under the different reforms. 
Table 2. Descriptive statistics

Mean Std. Dev.

\section{Treatment Variable}

YR

$15.24 \quad 4.50$

Instrumental Variable:

PYR

$12.23 \quad 3.72$

Outcomes:

\begin{tabular}{lll}
\hline Exercises regularly & 0.21 & 0.41 \\
Does not smoke & 0.66 & 0.47 \\
Does not drink alcohol regularly & 0.46 & 0.50 \\
Does not eat red meat at least once a day & 0.83 & 0.38 \\
Eats fruit or vegetables at least once a day & 0.85 & 0.36 \\
Does not drink soft drinks at least once a day & 0.86 & 0.34 \\
Not obese & 0.89 & 0.31 \\
Very satisfied with health & 0.20 & 0.40
\end{tabular}

Other covariates:

5-year college degre

$0.10 \quad 0.31$

3-year college degree

$0.01 \quad 0.1$

High school diploma

$0.32 \quad 0.47$

$\begin{array}{lll}\text { Professional high school diploma } & 0.08 & 0.27\end{array}$

$\begin{array}{lll}\text { Junior high school diploma } & 0.39 & 0.49\end{array}$

$\begin{array}{lll}\text { Primary school diploma } & 0.08 & 0.27\end{array}$

$\begin{array}{lll}\text { No schooling } & 0.01 & 0.08\end{array}$

$\begin{array}{lll}\text { Public employee } & 0.18 & 0.38\end{array}$

$\begin{array}{lll}\text { Self-employed } & 0.30 & 0.46\end{array}$

$\begin{array}{lll}\text { Lives in a luxury apartment } & 0.08 & 0.27\end{array}$

$\begin{array}{lll}\text { Lives in a standard apartment } & 0.67 & 0.47\end{array}$

$\begin{array}{lll}\text { Lives in social housing } & 0.14 & 0.35\end{array}$

$\begin{array}{lll}\text { Lives in a country house } & 0.03 & 0.17\end{array}$

Lives in sheltered housing $\quad 0.01 \quad 0.05$

$\begin{array}{lll}\text { No kids } & 0.19 & 0.39\end{array}$

$\begin{array}{lll}\text { Married } & 0.84 & 0.36\end{array}$

Works in physically demanding job $\quad 0.31 \quad 0.46$

Notes: Data for "YR" are from the Bank of Italy SHIW survey, all other data are from the ISTAT AVQ survey. Both samples includes male workers aged 40 to 49 who do not have missing values in the variables reported in the table. Total number of observations in SHIW: 8,549. Total number of observations in AVQ: 38,966. "Does not drink soft drinks at least once a day" is only observed since $1998(\mathrm{~N}=35,829)$ and "Not obese" since 2001 $(\mathrm{N}=25,862)$. "YR" is the actual work horizon, or the number of years before becoming eligible to retire according to the rules in place at the time of the interview and using the observed number of years of social security contributions. "PYR" is the potential work horizon, computed using the potential number of years of social security contributions. The excluded school degree is "doctorate or equivalent". The excluded occupational sector is "private employee". The excluded accommodation type is "villa or single house". 
Table 3. The effect of potential years to retirement $(P Y R)$ on healthy behaviours - OLS estimation - linear probability models.

\begin{tabular}{|c|c|c|c|c|c|c|c|}
\hline (1) & (2) & (3) & (4) & (5) & (6) & (7) & (8) \\
\hline $\begin{array}{l}\text { Exercise } \\
\text { regularly }\end{array}$ & $\begin{array}{c}\text { No } \\
\text { Smoking }\end{array}$ & $\begin{array}{l}\text { No } \\
\text { alcohol } \\
\text { regularly }\end{array}$ & $\begin{array}{c}\text { No red } \\
\text { meat } \\
\text { at least } \\
\text { once a } \\
\text { day }\end{array}$ & $\begin{array}{c}\text { Fruit or } \\
\text { vegetables } \\
\text { at least once } \\
\text { a day }\end{array}$ & $\begin{array}{c}\text { No soft } \\
\text { drinks } \\
\text { at least } \\
\text { once a } \\
\text { day }\end{array}$ & Not obese & $\begin{array}{c}\text { Very } \\
\text { satisfied } \\
\text { with health }\end{array}$ \\
\hline
\end{tabular}

Panel 1: includes age by school degree dummies, sector dummies and a cubic trend in cohort

$\begin{array}{lcccccccc}\text { PYR/100 } & 1.23^{* * *} & 1.21^{* * *} & 0.94^{* *} & 0.57^{*} & 0.31 & 0.67^{* *} & 0.53 & 0.70^{* *} \\ & (0.34) & (0.34) & (0.40) & (0.31) & (0.27) & (0.30) & (0.35) & (0.33) \\ \text { \% effect } & & & & & & & & \\ \text { w.r.t. mean } & 5.92^{* * *} & 1.83^{* * *} & 2.03^{* *} & 0.69^{*} & 0.36 & 0.78^{* *} & 0.59 & 3.47^{* *}\end{array}$

outcome

Panel 2: includes as additional covariates regional dummies, type of accommodation dummies, having kids, being married and working in physically demanding jobs

$\begin{array}{lcccccccc}\text { PYR/100 } & 1.22^{* * *} & 1.16^{* * *} & 0.86^{* *} & 0.53^{*} & 0.29 & 0.63^{* *} & 0.57 & 0.72^{* *} \\ & (0.33) & (0.34) & (0.40) & (0.30) & (0.27) & (0.30) & (0.35) & (0.32) \\ \text { \% effect } & & & & & & & & \\ \text { w.r.t.mean } & 5.86^{* * *} & 1.76^{* * *} & 1.86^{* *} & 0.63^{*} & 0.34 & 0.73^{* *} & 0.64 & 3.57^{* *}\end{array}$

outcome

Panel 3: includes as additional covariates with respect to Panel 2 the real GDP per capita, relative prices and regional trends in the relevant outcome for males aged 65-75

$\begin{array}{lcccccccc}\text { PYR/100 } & 1.21^{* * *} & 1.10^{* * *} & 0.84^{* *} & 0.53^{*} & 0.21 & 0.63^{* *} & 0.68^{*} & 0.72^{* *} \\ & (0.33) & (0.35) & (0.40) & (0.30) & (0.28) & (0.30) & (0.35) & (0.32) \\ \text { \% effect } & & & & & & & & \\ \text { w.r.t.mean } & 5.79^{* * *} & 1.67 * * * & 1.81^{* *} & 0.63^{*} & 0.25 & 0.73^{* *} & 0.76^{*} & 3.58^{* *}\end{array}$

outcome

Panel 4: as Panel 3 but with regional trends in the relevant outcome for males aged 25-30

$\begin{array}{lcccccccc}\text { PYR/100 } & 1.23^{* * *} & 1.10^{* * *} & 0.83^{* *} & 0.53^{*} & 0.23 & 0.61^{* *} & 0.67^{*} & 0.76^{* *} \\ & (0.33) & (0.35) & (0.40) & (0.30) & (0.28) & (0.30) & (0.35) & (0.32) \\ \text { \% effect } & & & & & & & & \\ \text { w.r.t. mean } & 5.88^{* * *} & 1.67^{* * *} & 1.8^{* *} & 0.64^{*} & 0.27 & 0.70^{* *} & 0.75^{*} & 3.8^{* *}\end{array}$

outcome

Panel 5: as Panel 4 but with regional trends in the outcome for females not in the labour force aged 40 to 49 .

$\begin{array}{lcccccccc}\text { PYR/100 } & 1.22^{* * *} & 1.10^{* * *} & 0.88^{* *} & 0.54^{*} & 0.16 & 0.61^{* *} & 0.67^{*} & 0.74^{* *} \\ \begin{array}{l}\text { \% effect } \\ \begin{array}{l}\text { w.r.t. mean } \\ \text { outcome }\end{array}\end{array} & 5.8 .33) & (0.35) & (0.40) & (0.30) & (0.28) & (0.30) & (0.35) & (0.32) \\ & & 1.67^{* * *} & 1.89^{* *} & 0.64^{*} & 0.18 & 0.71^{* *} & 0.75^{*} & 3.67^{* *}\end{array}$

Notes: the table reports the estimated effects of $P Y R / 100$ on the health behaviour listed at the top of each column. Percentage effects are computed with respect to the mean value of the outcome in the full sample. Total number of observations: 38,966; for "No soft drinks at least once a day": 35,829; for "Not Obese": 25,862. In Panel C, we include the relative price of recreational activities in the equation for exercising, tobacco in the equation for smoking, alcohol in the equation for alcohol, meat in the equation for red meat, fruit and vegetables in the equation for fruit and vegetables, soft drinks in the equation for soft drink, and overall food and recreational activities in the equation for obesity. All price data come from the Italian National Statistical Office. Standard errors clustered by cohort, school leaving age and sector in parentheses. ${ }^{* *}$ : significant at the $1 \%$ level; **: significant at the $5 \%$ level; *: significant at the $10 \%$ level. 
Table 4. Effects of potential years to retirement $(P Y R)$ on healthy behaviours - OLS estimation - linear probability models. By different groups. \% effects with respect to mean outcomes.

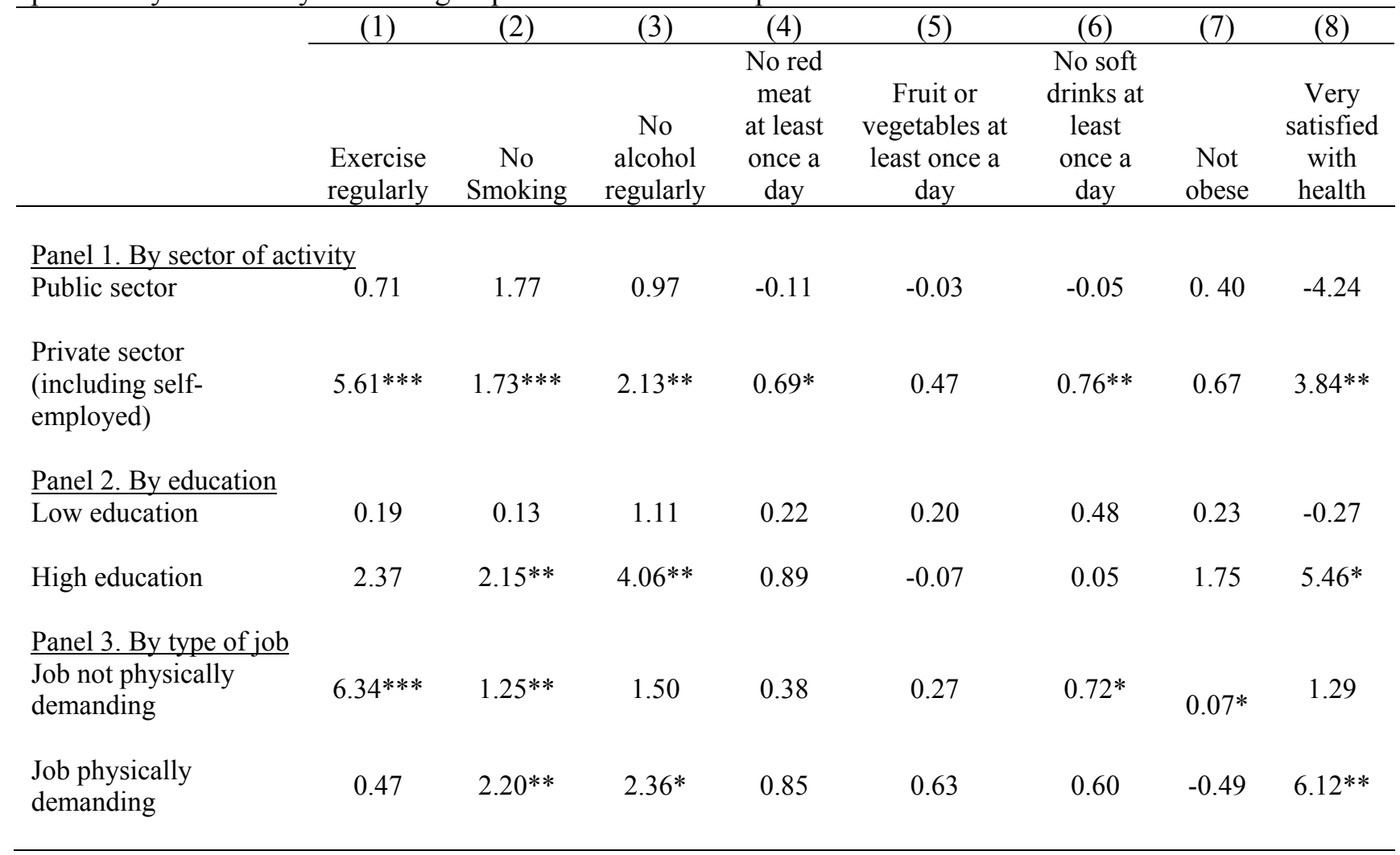

Notes: see Table 3 . 
Table 5. The effect of $Y R$ on healthy behaviours - Two-sample IV estimation - linear specification

\begin{tabular}{|c|c|c|c|c|c|c|c|c|}
\hline & (1) & (2) & (3) & (4) & (5) & (6) & (7) & (8) \\
\hline & $\begin{array}{l}\text { Exercise } \\
\text { regularly }\end{array}$ & $\begin{array}{c}\text { No } \\
\text { Smoking }\end{array}$ & $\begin{array}{l}\text { No } \\
\text { alcohol } \\
\text { regularly }\end{array}$ & $\begin{array}{c}\text { No red } \\
\text { meat } \\
\text { At least } \\
\text { once a } \\
\text { day }\end{array}$ & $\begin{array}{c}\text { Fruit or } \\
\text { vegetables } \\
\text { at least } \\
\text { once a } \\
\text { day }\end{array}$ & $\begin{array}{c}\text { No soft } \\
\text { drinks at } \\
\text { least once } \\
\text { a day }\end{array}$ & Not obese & $\begin{array}{c}\text { Very } \\
\text { satisfiec } \\
\text { with } \\
\text { health }\end{array}$ \\
\hline$Y R / 100$ & $\begin{array}{c}3.28 * * * \\
(1.25)\end{array}$ & $\begin{array}{l}3.22 * * \\
(1.27)\end{array}$ & $\begin{array}{c}2.5^{*} \\
(1.29)\end{array}$ & $\begin{array}{c}1.51 \\
(0.94)\end{array}$ & $\begin{array}{c}0.81 \\
(0.85)\end{array}$ & $\begin{array}{l}1.79^{*} \\
(1.03)\end{array}$ & $\begin{array}{c}1.4 \\
(1.13)\end{array}$ & $\begin{array}{l}1.85^{*} \\
(1.12)\end{array}$ \\
\hline $\begin{array}{l}\text { \% effect } \\
\text { w.r.t. mean } \\
\text { outcome }\end{array}$ & $15.74 * * *$ & $4.88 * *$ & $5.4 *$ & 1.82 & 0.96 & $2.07 *$ & 1.57 & $9.23 *$ \\
\hline $\begin{array}{l}\text { First-stage } \\
P Y R / 100\end{array}$ & $\begin{array}{c}0.38^{* * *} \\
(0.07)\end{array}$ & & & & & & & \\
\hline $\begin{array}{l}\text { First-stage } \\
\text { F statistic }\end{array}$ & & & & & & & & \\
\hline
\end{tabular}

Notes: the table reports the estimated effects of years to retirement $Y R$ on the health behaviours listed at the top of each column. Percentage effects are computed with respect to the mean of the outcome in the full sample. All regressions control for age by school degree dummies, sector dummies and a cubic trend in cohort, as in Table 3 - Panel A. The first stage is estimated in the SHIW sample for the years 1998-2010. Total number of observations in SHIW: 8,549. Bootstrapped standard errors clustered by cohort, school leaving age and sector in parentheses (1,000 bootstrap replications). ${ }^{* *}$ : significant at the $1 \%$ level; **: significant at the $5 \%$ level; *: significant at the $10 \%$ level. 


\section{Appendix}

1. An illustrative model

Following Galama et al., 2013, we consider an individual in his forties who intends to spend his residual lifetime partly at work and partly in retirement. In each period before retirement, his utility is given by

$$
\mathrm{U}_{\mathrm{wt}}=\mathrm{U}_{\mathrm{w}}\left(\mathrm{C}_{\mathrm{t}}, \mathrm{H}_{\mathrm{t}}\right)
$$

where $C$ is consumption and $H$ is the health stock in period $t$.

Let $\mathrm{B}_{\mathrm{t}}$ be a strictly positive measure of health investment (or healthy behaviour) and $\mathrm{p}_{t}$ its unit cost. ${ }^{20}$ For instance, this investment can be an healthy diet or physical exercise. The relationship between health and health investment is given by the following law of motion

$$
\frac{\partial \mathrm{H}_{\mathrm{t}}}{\partial \mathrm{t}}=\mu \mathrm{B}_{\mathrm{t}}-\sigma \mathrm{H}_{\mathrm{t}}
$$

By increasing $\mathrm{B}_{\mathrm{t}}$, the individual can compensate the natural decay of health. Using (A.2) we can write health at time $t$ as a function of initial health and of the entire history $0 \leq \mathrm{t}^{\prime}<\mathrm{t}$ of health investment $B_{t^{\prime}}$

$$
H_{t}=H_{0} e^{-\sigma t}+\int_{0}^{t} \mu B_{x} e^{-\sigma(t-x)} d x
$$

In the optimization problem, we optimize with respect to the entire prior history of health investment $\mathrm{B}_{\mathrm{t}^{\prime}}$ (Galama et al., 2008, p.5).

After retirement, individual utility is given by

$$
\mathrm{U}_{\mathrm{rt}}=\gamma \mathrm{U}_{\mathrm{r}}\left(\mathrm{C}_{\mathrm{t}}, \mathrm{H}_{\mathrm{t}}\right)
$$

where $\gamma>1$ indicates that "...a dollar with leisure - while retired - is better than a dollar that is only had together with work..." (Stock and Wise, 1990, p.213). Denoting assets with $A_{t}$, the intertemporal budget constraint is given by

$$
\frac{\partial \mathrm{A}_{t}}{\partial \mathrm{t}}=\delta \mathrm{A}_{\mathrm{t}}+\mathrm{Y}\left(\mathrm{H}_{\mathrm{t}}\right)-\mathrm{C}_{\mathrm{t}}-\mathrm{p}_{\mathrm{t}} \mathrm{B}_{\mathrm{t}}
$$

${ }^{20}$ We broadly interpret the unit cost as including both monetary and non-monetary costs. We assume that there are no corner solutions in the optimal choice of health investments. See Galama et al., 2013, for a discussion. 
where income $\mathrm{Y}$ is equal to yearly earnings $\mathrm{W}\left(\mathrm{H}_{\mathrm{t}}\right)$ before retirement and to $\Gamma$ (pension benefits) after retirement. $\mathrm{W}\left(\mathrm{H}_{\mathrm{t}}\right)$ is an increasing and concave function of $H$, the health stock. Better health affects earnings both by raising productivity and by increasing the probability of being gainfully employed, but - as in Galama et al., 2013 - in the model we do not distinguish further between these two channels.

Changes in minimum retirement age $R_{\min }$ affect individual choice only if $R_{\text {min }}$ is binding, that is, if optimal retirement age is lower than or equal to $\mathrm{R}_{\text {min }}$. We shall focus on this case. The individual chooses consumption and healthy behaviours to maximize the following inter-temporal utility

$$
\operatorname{Max} \int_{\mathrm{s}}^{\mathrm{R}_{\min }}\left[\mathrm{U}_{\mathrm{wt}}\left(\mathrm{C}_{\mathrm{t}}, \mathrm{H}_{\mathrm{t}}\right)\right] \mathrm{e}^{-\mathrm{rt}} \mathrm{dt}+\int_{\mathrm{R}_{\min }}^{\mathrm{T}}\left[\gamma \mathrm{U}_{\mathrm{rt}}\left(\mathrm{C}_{\mathrm{t}}, \mathrm{H}_{\mathrm{t}}\right)\right] \mathrm{e}^{-\mathrm{rt}} \mathrm{dt}
$$

subject to (A.3) and (A.5), where T denotes total lifetime, that we assume to be independent of health, as in Galama et al., 2013, $s$ is initial age and $r$ is the interest rate. Following Galama et al., 2008 , this is equivalent to maximizing

$$
\operatorname{Max} \int_{s}^{R_{\min }}\left[U_{w t}\left(C_{t}, H_{t}\right)\right] e^{-r t} d t+\int_{R_{\min }}^{T}\left[\gamma U_{r t}\left(C_{t}, H_{t}\right)\right] e^{-r t} d t+\lambda_{0} \int_{s}^{T}\left[\delta A_{t}+Y\left(H_{t}\right)-C_{t}-p_{t} B_{t}\right] e^{-\delta t} d t
$$

where $\lambda_{t}=\lambda_{0} \mathrm{e}^{-\delta \mathrm{t}}$ is the co-state variable associated to (A.5). The first order necessary condition for optimal $B_{t^{\prime}}$ when $t^{\prime} \leq R_{\min }$ is

$$
\int_{\mathrm{t}^{\prime}}^{\mathrm{R}_{\min }}\left[\frac{\partial \mathrm{U}_{\mathrm{wt}}}{\partial \mathrm{H}_{\mathrm{t}}} \frac{\partial \mathrm{H}_{\mathrm{t}}}{\partial \mathrm{B}_{\mathrm{t}^{\prime}}}\right] \mathrm{e}^{-\mathrm{rt}} \mathrm{dt}+\int_{\mathrm{R}_{\min }}^{\mathrm{T}}\left[\gamma \frac{\partial \mathrm{U}_{\mathrm{rt}}}{\partial \mathrm{H}_{\mathrm{t}}} \frac{\partial \mathrm{H}_{\mathrm{t}}}{\partial \mathrm{B}_{\mathrm{t}^{\prime}}}\right] \mathrm{e}^{-\mathrm{rt}} \mathrm{dt}-\lambda_{0} \int_{\mathrm{t}^{\prime}}^{\mathrm{T}}\left[\mathrm{p}_{\mathrm{t}}-\frac{\partial \mathrm{Y}\left(\mathrm{H}_{\mathrm{t}}\right)}{\partial \mathrm{H}_{\mathrm{t}}} \frac{\partial \mathrm{H}_{\mathrm{t}}}{\partial \mathrm{B}_{\mathrm{t}^{\prime}}}\right] \mathrm{e}^{-\delta \mathrm{t}} \mathrm{dt}=\phi\left(\mathrm{B}_{\mathrm{t}^{\prime}}, \mathrm{Z}, \mathrm{p}_{\mathrm{t}}\right)=0
$$

For consumption, the first order condition is

$$
\frac{\partial \mathrm{U}_{\mathrm{wt}}}{\partial \mathrm{C}_{\mathrm{t}^{\prime}}}-\lambda_{0} \mathrm{e}^{(\mathrm{r}-\delta) \mathrm{t}^{\prime}}=0=\chi\left(\mathrm{B}_{\mathrm{t}^{\prime}}, \mathrm{C}_{\mathrm{t}^{\prime}}\right)
$$

At the optimum, health investment when $t^{\prime} \leq R_{\text {min }}$ equalizes the marginal benefits during both active working life $\int_{\mathrm{t}^{\prime}}^{\mathrm{R}_{\min }}\left[\frac{\partial \mathrm{U}_{\mathrm{wt}}}{\partial \mathrm{H}_{\mathrm{t}}} \frac{\partial \mathrm{H}_{\mathrm{t}}}{\partial \mathrm{B}_{\mathrm{t}^{\prime}}}\right] \mathrm{e}^{-\mathrm{rt}} \mathrm{dt}$ and after retirement $\int_{\mathrm{R}_{\min }}^{\mathrm{T}}\left[\gamma \frac{\partial \mathrm{U}_{\mathrm{rt}}}{\partial \mathrm{H}_{\mathrm{t}}} \frac{\partial \mathrm{H}_{\mathrm{t}}}{\partial \mathrm{B}_{\mathrm{t}^{\prime}}}\right] \mathrm{e}^{-\mathrm{rt}} \mathrm{dt}$ and the net marginal costs $\lambda_{0} \int_{\mathrm{t}^{\prime}}^{\mathrm{T}}\left[\mathrm{p}_{\mathrm{t}}-\frac{\partial \mathrm{Y}\left(\mathrm{H}_{\mathrm{t}}\right)}{\partial \mathrm{H}_{\mathrm{t}}} \frac{\partial \mathrm{H}_{\mathrm{t}}}{\partial \mathrm{B}_{\mathrm{t}^{\prime}}}\right] \mathrm{e}^{-\delta \mathrm{t}} \mathrm{dt}$.

Since the contribution of health to wages ends with retirement, we can re-write (A.8) as follows 


$$
\begin{aligned}
& \left.\int_{\mathrm{t}^{\prime}}^{\mathrm{R}_{\min }}\left[\frac{\partial \mathrm{U}_{\mathrm{wt}}}{\partial \mathrm{H}_{\mathrm{t}}} \frac{\partial \mathrm{H}_{\mathrm{t}}}{\partial \mathrm{B}_{\mathrm{t}^{\prime}}}\right] \mathrm{e}^{-\mathrm{rt}} \mathrm{dt}+\lambda_{0} \int_{\mathrm{t}^{\prime}}^{\mathrm{R}_{\min }} \frac{\partial \mathrm{Y}\left(\mathrm{H}_{\mathrm{t}}\right)}{\partial \mathrm{H}_{\mathrm{t}}} \frac{\partial \mathrm{H}_{\mathrm{t}}}{\partial \mathrm{B}_{\mathrm{t}^{\prime}}}\right] \mathrm{e}^{-\delta \mathrm{t}} \mathrm{dt} \\
& +\int_{\mathrm{R}_{\min }}^{\mathrm{T}}\left[\gamma \frac{\partial \mathrm{U}_{\mathrm{rt}}}{\partial \mathrm{H}_{\mathrm{t}}} \frac{\partial \mathrm{H}_{\mathrm{t}}}{\partial \mathrm{B}_{\mathrm{t}^{\prime}}}\right] \mathrm{e}^{-\mathrm{rt}} \mathrm{dt}-\lambda_{0} \int_{\mathrm{t}^{\prime}}^{\mathrm{T}} \mathrm{p}_{\mathrm{t}} \mathrm{e}^{-\delta \mathrm{t}} \mathrm{dt}=\phi\left(\mathrm{B}_{\mathrm{t}^{\prime}}, \mathrm{C}_{\mathrm{t}^{\prime}}, \mathrm{R}_{\min }, \mathrm{p}_{\mathrm{t}}\right)=0
\end{aligned}
$$

Totally differentiating (A.8) and (A.9) with respect to $\mathrm{R}_{\min }, \mathrm{B}_{\mathrm{t}^{\prime}}$ and $\mathrm{C}_{\mathrm{t}^{\prime}}$, we obtain

$$
\begin{aligned}
& \phi_{1} \mathrm{~dB}_{\mathrm{t}^{\prime}}+\phi_{2} \mathrm{dC}_{\mathrm{t}^{\prime}}+\phi_{3} \mathrm{dR}_{\text {min }}=0 \\
& \chi_{1} \mathrm{~dB}_{\mathrm{t}^{\prime}}+\chi_{2} \mathrm{dC}_{\mathrm{t}^{\prime}}=0 \\
& \text { where } \phi_{\mathrm{i}}=\frac{\partial \phi}{\partial \mathrm{Z}} \text { and } \mathrm{Z} \text { includes } \mathrm{R}_{\text {min }}, \mathrm{B}_{\mathrm{t}^{\prime}} \text { and } \mathrm{C}_{\mathrm{t}^{\prime}} .
\end{aligned}
$$

By Cramer's rule, we get that

$$
\frac{\partial \mathrm{B}_{\mathrm{t}^{\prime}}}{\partial \mathrm{R}_{\min }}=\frac{-\chi_{2} \phi_{3}}{\Delta}
$$

where $\Delta=\phi_{1} \chi_{2}-\phi_{2} \chi_{1}>0$ because of the second order conditions. Since $\chi_{2}$ is negative, the sign of $\frac{\partial \mathrm{B}_{\mathrm{t}^{\prime}}}{\partial \mathrm{R}_{\min }}$ depends on the sign of $\phi_{3}$ and is positive if $\phi_{3}=\frac{\partial \mathrm{U}_{\mathrm{wR}}}{\partial \mathrm{H}_{\mathrm{R}_{\min }}}+\lambda_{0} \frac{\partial \mathrm{Y}\left(\mathrm{H}_{\mathrm{R}_{\min }}\right)}{\partial \mathrm{H}_{\mathrm{R}_{\min }}} \mathrm{e}^{(\mathrm{r}-\delta) \mathrm{R}}-\gamma \frac{\partial \mathrm{U}_{\mathrm{rR}}}{\partial \mathrm{H}_{\mathrm{R}_{\min }}}>0$

In words, postponing minimum retirement age increases optimal healthy behaviours before retirement if the benefits of a longer working life induced by better health are higher than costs in terms of leisure due to a shorter retirement period.

For the individuals who are not bound by minimum retirement age, optimal age $\mathrm{R}$ can be determined by inserting the optimal values of $C_{t}, H_{t}$ and $B_{t}$ into the indirect utility function $V(R)$ and differentiating this function with respect to R. Galama et al., 2013, solve numerically for optimal retirement age $\mathrm{R}$.

When $\frac{\partial \mathrm{B}_{\mathrm{t}^{\prime}}}{\partial \mathrm{R}_{\min }}>0$, the individual increases her healthy behaviours before retirement, and by so doing increases her health stock. After retirement, when $t^{\prime}>R_{\text {min }}$, he maximizes $\operatorname{Max} \int_{t^{\prime}}^{T}\left[\gamma U_{r t}\left(C_{t}, H_{t}\right)\right] e^{-r t} d t+\lambda_{0} \int_{s}^{T}\left[\delta A_{t}+\Gamma_{t}-C_{t}-p_{t} B_{t}\right] e^{-\delta t} d t$

The first order necessary condition for optimal $\mathrm{B}_{\mathrm{t}^{\prime}}$ is 
$\int_{\mathrm{t}^{\prime}}^{\mathrm{T}}\left[\gamma \frac{\partial \mathrm{U}_{\mathrm{rt}}}{\partial \mathrm{H}_{\mathrm{t}}} \frac{\partial \mathrm{H}_{\mathrm{t}}}{\partial \mathrm{B}_{\mathrm{t}^{\prime}}}\right] \mathrm{e}^{-\mathrm{rt}} \mathrm{dt}-\lambda_{0} \int_{\mathrm{t}^{\prime}}^{\mathrm{T}} \mathrm{p}_{\mathrm{t}} \mathrm{e}^{-\delta \mathrm{t}} \mathrm{dt}=0$

Since the marginal utility of health is decreasing in the health stock, and the health stock at retirement is higher because of the postponed minimum retirement age, both the marginal benefits of additional health investments and the investments themselves are likely to fall just after retirement when $\mathrm{R}_{\min }$ increases. 


\section{Tables}

Table A1. Old-age pension eligibility during the sample period (1997-2011)

\begin{tabular}{lccc}
\hline \multicolumn{1}{c}{$\begin{array}{c}\text { Sector: } \\
\begin{array}{l}\text { Retirement } \\
\text { year: }\end{array}\end{array}$} & Private & Public & Self-employed \\
\hline 1997 & Age \& YContr & Age \& YContr & Age \& YContr \\
1998 & $63+18$ & $65+18$ & $63+18$ \\
1999 & $64+18$ & $65+18$ & $64+18$ \\
2000 & $65+19$ & $65+19$ & $64+19$ \\
2001 onwards & $65+20$ & $65+19$ & $65+19$ \\
\hline
\end{tabular}

Note: Y Contr: years of paid contributions.

Table A2. Old-age pension eligibility according to the different reforms in place during the sample period (1997-2011)

a. "Dini” reform. Survey years of application: 1997

\begin{tabular}{|c|c|c|c|c|c|c|}
\hline \multirow{2}{*}{$\begin{array}{l}\text { Sector: } \\
\text { Retirement } \\
\text { year: }\end{array}$} & \multicolumn{2}{|c|}{ Private } & \multicolumn{2}{|c|}{ Public } & \multicolumn{2}{|c|}{ Self-employed } \\
\hline & Age \& YContr & Only YContr & Age \& YContr & Only YContr & Age \& YContr & Only YContr \\
\hline 1997 & $52 \& 35$ & 36 & $52+35$ & 36 & $56+35$ & 40 \\
\hline 1998 & $53 \& 35$ & 36 & $53 \& 35$ & 36 & $57 \& 35$ & 40 \\
\hline 1999 & $53 \& 35$ & 37 & $53 \& 35$ & 37 & $57 \& 35$ & 40 \\
\hline 2000 & $54 \& 35$ & 37 & $54 \& 35$ & 37 & $57 \& 35$ & 40 \\
\hline 2001 & $54 \& 35$ & 37 & $54 \& 35$ & 37 & $57 \& 35$ & 40 \\
\hline 2002 & $55 \& 35$ & 37 & $55 \& 35$ & 37 & $57 \& 35$ & 40 \\
\hline 2003 & $55 \& 35$ & 37 & $55 \& 35$ & 37 & $57 \& 35$ & 40 \\
\hline 2004 & $56 \& 35$ & 38 & $56 \& 35$ & 38 & $57 \& 35$ & 40 \\
\hline 2005 & $56 \& 35$ & 38 & $56 \& 35$ & 38 & $57 \& 35$ & 40 \\
\hline 2006 & $57 \& 35$ & 39 & $57 \& 35$ & 39 & $57 \& 35$ & 40 \\
\hline 2007 & $57 \& 35$ & 39 & $57 \& 35$ & 39 & $57 \& 35$ & 40 \\
\hline 2008 onwards & $57 \& 35$ & 40 & $57 \& 35$ & 40 & $57 \& 35$ & 40 \\
\hline
\end{tabular}

b. "Prodi" reform. Years of application: 1998-2004

\begin{tabular}{lcccccc}
\hline \multirow{2}{*}{$\begin{array}{c}\text { Sector: } \\
\text { Retirement } \\
\text { year: }\end{array}$} & \multicolumn{2}{c}{ Private } & \multicolumn{2}{c}{ Public } & \multicolumn{2}{c}{ Self-employed } \\
\hline 1998 & Age \& YContr & Only YContr & Age \& YContr & Only YContr & Age \& YContr & Only YContr \\
1999 & $54 \& 35$ & 36 & $53 \& 35$ & 36 & $57 \& 35$ & 40 \\
2000 & $55 \& 35$ & 37 & $53 \& 35$ & 37 & $57 \& 35$ & 40 \\
2001 & $55 \& 35$ & 37 & $54 \& 35$ & 37 & $57 \& 35$ & 40 \\
2002 & $56 \& 35$ & 37 & $55 \& 35$ & 37 & $58 \& 35$ & 40 \\
2003 & $57 \& 35$ & 37 & $55 \& 35$ & 37 & $58 \& 35$ & 40 \\
2004 & $57 \& 35$ & 37 & $56 \& 35$ & 37 & $58 \& 35$ & 40 \\
2005 & $57 \& 35$ & 38 & $57 \& 35$ & 38 & $58 \& 35$ & 40 \\
2006 & $57 \& 35$ & 38 & $57 \& 35$ & 38 & $58 \& 35$ & 40 \\
2007 & $57 \& 35$ & 39 & $57 \& 35$ & 39 & $58 \& 35$ & 40 \\
2008 onwards & $57 \& 35$ & 39 & $57 \& 35$ & 39 & $58 \& 35$ & 40 \\
\hline
\end{tabular}


c. "Maroni" reform. Years of application: 2005-2007

\begin{tabular}{lcccccc}
\hline \multicolumn{1}{c}{$\begin{array}{c}\text { Sector: } \\
\begin{array}{l}\text { Retirement } \\
\text { year: }\end{array}\end{array}$} & Private & \multicolumn{2}{c}{ Public } & \multicolumn{2}{c}{ Self-employed } \\
\hline 2005 & $57 \& 35$ & 38 & $57 \& 35$ & 38 & $58 \& 35$ & 40 \\
2006 & $57 \& 35$ & 39 & $57 \& 35$ & 39 & $58 \& 35$ & 40 \\
2007 & $57 \& 35$ & 39 & $57 \& 35$ & 39 & $58 \& 35$ & 40 \\
2008 & $60 \& 35$ & 40 & $60 \& 35$ & 40 & $61 \& 35$ & 40 \\
2009 & $60 \& 35$ & 40 & $60 \& 35$ & 40 & $61 \& 35$ & 40 \\
2010 onwards & $61 \& 35$ & 40 & $61 \& 35$ & 40 & $62 \& 35$ & 40 \\
\hline
\end{tabular}

d. "Prodi bis" reform. Years of application: 2005-2007

\begin{tabular}{|c|c|c|c|c|c|c|}
\hline \multirow{2}{*}{$\begin{array}{l}\text { Sector: } \\
\text { Retirement } \\
\text { year: }\end{array}$} & \multicolumn{2}{|c|}{ Private } & \multicolumn{2}{|c|}{ Public } & \multicolumn{2}{|c|}{ Self-employed } \\
\hline & $\begin{array}{r}\text { Age \& YContr \& } \\
\text { (Age+ YContr) }\end{array}$ & Only YContr & $\begin{array}{r}\text { Age \& YContr \& } \\
\text { (Age+ YContr) }\end{array}$ & Only YContr & $\begin{array}{r}\text { Age \& YContr \& } \\
\text { (Age+ YContr) }\end{array}$ & Only YContr \\
\hline 2008 & $58 \& 35$ & 40 & $58 \& 35$ & 40 & $59+35$ & 40 \\
\hline 2009 & $59 \& 35 \& 95$ & 40 & $59 \& 35 \& 95$ & 40 & $60+35,96$ & 40 \\
\hline 2010 & $59 \& 35 \& 95$ & 40 & $59 \& 35 \& 95$ & 40 & $60+35,96$ & 40 \\
\hline 2011 & $60 \& 35 \& 96$ & 40 & $60 \& 35 \& 96$ & 40 & $61+35,97$ & 40 \\
\hline 2012 & $60 \& 35 \& 96$ & 40 & $60 \& 35 \& 96$ & 40 & $61+35,97$ & 40 \\
\hline 2013 onwards & $61 \& 35 \& 97$ & 40 & $61 \& 35 \& 97$ & 40 & $62+35,98$ & 40 \\
\hline
\end{tabular}

Notes: see Table A1. The requirement in terms of (age+ YContr) only applies since 2009 
Table A3. The effect of years to retirement (PYR) on health behaviours - marginal effects from Probit estimation - linear specification

\begin{tabular}{|c|c|c|c|c|c|c|c|c|}
\hline & (1) & (2) & (3) & (4) & (5) & (6) & (7) & (8) \\
\hline & $\begin{array}{l}\text { Sports } \\
\text { regularly }\end{array}$ & $\begin{array}{c}\text { Not a } \\
\text { Smoker }\end{array}$ & $\begin{array}{c}\text { No } \\
\text { alcohol } \\
\text { daily } \\
\end{array}$ & $\begin{array}{c}\text { No red } \\
\text { meat } \\
\text { daily }\end{array}$ & $\begin{array}{c}\text { Fruit or } \\
\text { vegetables } \\
\text { daily }\end{array}$ & $\begin{array}{c}\text { No soft } \\
\text { drinks } \\
\text { daily }\end{array}$ & $\begin{array}{c}\text { Not } \\
\text { obese }\end{array}$ & $\begin{array}{l}\text { Very } \\
\text { satisfied } \\
\text { with } \\
\text { health } \\
\end{array}$ \\
\hline PYR/100 & $\begin{array}{c}3.78^{* * *} \\
(1.20)\end{array}$ & $\begin{array}{c}3.82 * * * \\
(0.96)\end{array}$ & $\begin{array}{r}2.46^{* *} \\
(1.05)\end{array}$ & $\begin{array}{l}2.16^{*} \\
(1.24)\end{array}$ & $\begin{array}{c}0.92 \\
(1.19)\end{array}$ & $\begin{array}{l}2.56^{*} \\
(1.45)\end{array}$ & $\begin{array}{l}2.57 \\
(2.14)\end{array}$ & $\begin{array}{l}2.50^{* *} \\
(1.16)\end{array}$ \\
\hline \multicolumn{9}{|l|}{$\begin{array}{l}\% \text { effect } \\
\text { w.r.t. } \\
\text { mean }\end{array}$} \\
\hline \multicolumn{9}{|c|}{$\begin{array}{l}\text { Notes: the table reports the estimated average marginal effects of PYR on the health behaviour listed at the } \\
\text { top of each column, obtained from Probit models. The controls included in the regressions reported in this } \\
\text { table are those in Table } 3 \text { - Panel } 1 \text {. Results for estimates with a richer set of controls are available from the } \\
\text { authors upon request. }\end{array}$} \\
\hline \multicolumn{9}{|c|}{$\begin{array}{l}\text { Table A4. The effect of potential years to retirement }(P Y R) \text { on health behaviours - OLS estimation - } \\
\text { quadratic specification }\end{array}$} \\
\hline & (1) & $(2)$ & (3) & $(4)$ & (5) & $(6)$ & (7) & $(8)$ \\
\hline & $\begin{array}{l}\text { Sports } \\
\text { regularly }\end{array}$ & $\begin{array}{l}\text { Not a } \\
\text { Smoker }\end{array}$ & $\begin{array}{c}\text { No } \\
\text { alcohol } \\
\text { daily }\end{array}$ & $\begin{array}{c}\text { No red } \\
\text { meat } \\
\text { daily }\end{array}$ & $\begin{array}{c}\text { Fruit or } \\
\text { vegetable } \\
\text { s daily }\end{array}$ & $\begin{array}{c}\text { No soft } \\
\text { drinks } \\
\text { daily }\end{array}$ & $\begin{array}{c}\text { Not } \\
\text { obese }\end{array}$ & $\begin{array}{c}\text { Very } \\
\text { satisfi } \\
\text { ed } \\
\text { with } \\
\text { health } \\
\end{array}$ \\
\hline PYR/100 & $\begin{array}{c}0.02 \\
(0.60)\end{array}$ & $\begin{array}{c}1.57 \\
(0.96)\end{array}$ & $\begin{array}{c}2.19 * * * \\
(0.79)\end{array}$ & $\begin{array}{c}0.73 \\
(0.72)\end{array}$ & $\begin{array}{l}-0.18 \\
(0.63)\end{array}$ & $\begin{array}{c}0.21 \\
(0.63)\end{array}$ & $\begin{array}{c}0.50 \\
(1.65)\end{array}$ & $\begin{array}{c}1.23 \\
(0.86)\end{array}$ \\
\hline $\mathrm{PYR} / 100^{2}$ & $\begin{array}{l}0.05^{*} \\
(0.03)\end{array}$ & $\begin{array}{l}-0.01 \\
(0.03)\end{array}$ & $\begin{array}{l}-0.05^{*} \\
(0.03)\end{array}$ & $\begin{array}{l}-0.01 \\
(0.02)\end{array}$ & $\begin{array}{c}0.02 \\
(0.02)\end{array}$ & $\begin{array}{c}0.02 \\
(0.02)\end{array}$ & $\begin{array}{c}0.00 \\
(0.05)\end{array}$ & $\begin{array}{l}-0.02 \\
(0.03)\end{array}$ \\
\hline
\end{tabular}

Notes: see Table 3 . The controls included in the regressions reported in this table are those in Table 3 - Panel A. Results for estimates with a richer set of controls are available from the authors upon request. 


\section{References}

- Adam, S., Bonsang, E., and Perelman, S., 2012. Does retirement affect cognitive functioning? Journal of Health Economics, 31(3), 490-501.

- Angelini, V., Brugiavini, A., and Weber, G., 2009. Ageing and unused capacity in Europe: is there an early retirement trap? Economic Policy, 24(59), 463-508.

- Angrist, J. D. and Krueger, A. B., 1992. The effect of age at school entry on educational attainment: An application of instrumental variables with moments from two samples. Journal of American Statistical Association, 87(418), 328-336

- Battistin, E., Brugiavini, A., Rettore, E., and Weber, G., 2009. The Retirement Consumption Puzzle: Evidence from a Regression Discontinuity Approach. American Economic Review, 99(5): 2209-26.

- Battistin, E., De Nadai, M., and Padula, M., 2014. Roadblocks on the Road to Grandma's House: Fertility Consequences of Delayed Retirement. IZA Discussion Paper n. 8071.

- Bertoni, M., Maggi, S. and Weber, G, 2015. Work, retirement and muscle strength loss in old age. Mimeo, University of Padova.

- Bertoni, M., and Brunello, G., 2014. Pappa ante Portas: The Retired Husband Syndrome in Japan. IZA DP n. 8350.

- Bonsang, E. and Klein, T. J., 2012. Retirement and subjective well-being. Journal of Economic Behavior and Organization, 83(3), 311-329.

- Börsch-Supan, A., and Jürges, H., 2009. Early retirement, social security and well-being in Germany. NBER Working Paper n. 12303.

- Bottazzi, R., Jappelli, T. and Padula, M., 2006. Retirement expectations, pension reforms, and their impact on private wealth accumulation. Journal of Public Economics, 90 (12), 2187-2212.

- Bottazzi, R., Jappelli, T. and Padula, M., 2011. The portfolio effect of pension reforms: evidence from Italy. Journal of Pensions Economics and Finance. 10 (1), 75-97.

- Brunello G. and Comi S., 2015, The side effect of pension reforms on the training of older workers. Evidence from Italy. Journal of Economics of Ageing, 113-122.

- Cawley J. and Ruhm C., 2011 The economics of risky health behaviors. NBER Working Paper No. w17081.

- Celidoni, M., Dal Bianco, C. and Weber, G., 2013. Early retirement and cognitive decline. A longitudinal analysis using SHARE data. "Marco Fanno" Working Paper n. 174, Department of Economics and Management, University of Padua

- Celidoni, M., and Rebba, V., 2015. Healthier lifestyles after retirement in Europe? Evidence from SHARE. "Marco Fanno" Working Paper n. 201, Department of Economics and Management, University of Padua

- Coe, N. B., and Zamarro, G., 2011. Retirement effects on health in Europe. Journal of Health Economics, 30(1), 77-86.

- Charles, K. K., 2004. Is retirement depressing? Labor force inactivity and psychological wellbeing later in life. Research in Labor Economics, 23, 269-299.

- Clark, A. E. and Fawaz, Y., 2009. Valuing jobs via retirement: European evidence. National Institute Economic Review, 209(1), 88-103.

- De Grip, A., Lindeboom, M., and Montizaan, R., 2012. Shattered dreams: The effects of changing the pension system late in the game. Economic Journal, 122 (559), 1-25.

- Eibich, P., 2015. Understanding the effect of retirement on health: Mechanisms and heterogeneity. Journal of Health Economics, 43, 1-12. 
- Fonseca, R., Kapteyn, A., Lee, J., and Zamarro, G., 2015. Does Retirement Make you Happy? A Simultaneous Equations Approach. A Simultaneous Equations Approach. In: Wise, D.A. (ed.), Insights in the Economics of Aging. Chicago: University of Chicago Press.

- Galama, T., Kapteyn, A., Fonseca, R. and Michaud, P. C., 2013, A Health Production Model with Endogenous Retirement, Health Economics, 22, 883-902.

- Godard, M., 2016. Gaining weight through retirement? Results from the SHARE study. Journal of Health Economics, 45, 27-46.

- Grossman, M., 2000. The human capital model. In: A. J. Culyer \& J. P. Newhouse (ed.), Handbook of Health Economics. Elsevier.

- Hairault, J. O., Sopraseuth, T., and Langot, F., 2010. Distance to retirement and older workers“ employment: The case for delaying the retirement age. Journal of the European Economic association, 8(5), 1034-1076.

- Imbens, G. W., and Angrist, J. D., 1994. Identification and Estimation of Local Average Treatment Effects. Econometrica, 62(2), 467-475.

- Inoue, A., \& Solon, G. 2010, Two-sample instrumental variables estimators. The Review of Economics and Statistics, 92(3), 557-561.

- Insler, M., 2014. The health consequences of retirement. Journal of Human Resources, 49(1), 195-233.

- Johnston, D.W., \& Lee, W., 2009, Retiring to the good life? The short-term effects of retirement on health, Economics Letters, 103 (1), 8-11.

- Kaempfen, F., \& Maurer, J., 2016. Time to burn (calories)? The impact of retirement on physical activity among mature Americans. Journal of Health Economics, 45, 91-102.

- Mazzonna, F. \& Peracchi, F., 2012. Aging, cognitive abilities and retirement. European Economic Review, 56(4), 691-710.

- Mazzonna, F. \& Peracchi, F., 2014. Unhealthy retirement? EIEF working paper 09/14

- Manacorda, M., \& Moretti, E., 2006. Why do Most Italian Youths Live with Their Parents? Intergenerational Transfers and Household Structure. Journal of the European Economic Association, 4(4), 800-829.

- Montizaan R., Cörvers, F., and de Grip, A., 2010. The Effects of Pension Rights and Retirement Age on Training Participation: Evidence from a Natural Experiment. Labour Economics, 2010, 17 (1), 240-247.

- Montizaan, R. and Vendrik, M. C. M., 2014. Misery Loves Company: Exogenous Shocks in Retirement Expectations and Social Comparison Effects on Subjective Well-Being. Journal of Economic Behavior and Organization, 97, 1-26.

- OECD, 2015. Health at a Glance 2015: OECD Indicators. OECD publishing, Paris.

- Rohwedder, S., \& Willis, R. J. 2010. Mental retirement. The Journal of Economic Perspectives, 24(1), 119.

- Stock, J. H., Wise, D.A., 1990. The Pension Inducement to Retire: An Option Value Analysis, in Wise DA (ed.), Issues in the Economics of Ageing, University of Chicago Press, Chicago.

- Zhao, M., Konishi, Y. and Noguchi, H., 2013. Retiring for Better Health? Evidence from Health Investment Behaviors in Japan. Waseda University WIAS Discussion Paper no. 20 